Piotr Łuszczykiewicz

\title{
Seks, taśmy i statusy Facebooka. O poezji Katarzyny Fetlińskiej
}

W 2015 roku nakładem Biura Literackiego ukazały się Sekstaśmy, drugi tom poetycki Katarzyny Fetlińskiej'. W debiutanckich Glossolaliach (2012) autorka nawiązywała do sztuk plastycznych tytuły poszczególnych wierszy ewokowały konkretne dzieła wizualne, których protagonistom poetka użyczała głosu. Teraz oddała też głos sobie, ponieważ oprócz książki w skład Sekstaśm wchodzi płyta CD - audiobook z autorskimi interpretacjami wierszy. Spośród dwudziestu dwóch tekstów niemal każdy - prócz inicjalnego wiersza High definition - zadedykowany jest konkretnej osobie.

Przeczytajmy opis tomiku umieszczony w internetowym serwisie, kierując się intuicją, że nic tak nie morduje książki jak redakcyjny blurb:

Sekstaśmy to poruszająca, podszyta błyskotliwym humorem opowieść o współczesności. W zdigitalizowanym, a jednak

Urodziła się w Ciechanowie (1991), studentka filologii angielskiej na Uniwersytecie Warszawskim, publikowała w czasopismach: „Rita Baum”, „Pogranicza”, „Neurokultura” oraz w antologii Połów. Poetyckie debiuty [2011]. Prowadzi licznie odwiedzaną stronę na Facebooku: www. facebook.com/katarzyna.fetlinska. 
na wskroś biologicznym, świecie bohaterami Katarzyny Fetlińskiej rządzi ciało - świadome własnej powłoki, choć często nieświadomie zmieniające się pod wpływem nowych technologii. Poetka bada, jak poezja wpływa na umysł i ciało człowieka, jakie wyzwala emocje i jakie przemyślenia budzi².

Fonia i wizja oddane zostają tutaj zarazem - jakby na spóźnione zamówienie dyrektyw poetyki odbioru - bohaterom dedykacji wierszy, gdyż - jak głosi cytat z zapowiadającej tomik informacji Biura Literackiego -

częścią projektu Katarzyny Fetlińskiej są również krótkie, dokumentalne „reaction videos”, zamieszczane regularnie w serwisie YouTube. Autorka spotykała się z osobami, którym dedykowała wiersze - odtworzywszy w ich obecności właściwe nagranie studyjne, filmowała reakcje, emocje, wypowiedzi złożone z wspomnień oraz skojarzeń związanych $\mathrm{z}$ utworem ${ }^{3}$.

I jeszcze jeden cytat z tzw. towarzyszącej krytyki redakcyjnej, niczym ostateczny cios łopatą przed wrzuceniem do dołu literackiej nieważności i przysypaniem ziemią zapomnienia. Grobowy wzgórek zostaje zgrabnie oklepany łopatą wydawcy:

„Jesteśmy złudzeni” - pisze Fetlińska w High definition, wierszu-manifeście otwierającym tom. To określenie doprecyzowuje klimat poetycki Sekstaśm. Ludzie, podlegli wyobrażeniom, wspomnieniom i obietnicom, przestają wierzyć we własną realność i integralność. Tworzą w nieskończoność złudzenia dotyczące wszystkiego, co ich otacza. Jednocześnie stanowią produkt własnych złudzeń. 
Jak zauważa Joanna Żabicka: „jedną z ciekawszych stron tej poezji jest próba ułożenia się z czasem, którego względność wynika z dwojakiej - i nie do końca sprecyzowanej - funkcji, jaką w jego kontekście pełni człowiek. Postaci często stają się tutaj przedmiotami, i to przedmiotami oddziaływania materii nieożywionej”. I dodaje: „Sensualna intensywność Sekstaśm bierze się być może z przemożnego poczucia podmiotu, że to, co ma miejsce, jest niepowtarzalne.

Wszystkie wyobrażenia i oczekiwania nie mają, w gruncie rzeczy, nic wspólnego z przyszłością. Świat zatrzaśnięty w kadrze, ludzie zatrzymani w bursztynie - to jedyny dostępny nam, odbiorcom, moment. Możemy więc - jako widzowie lub bohaterowie tego świata - marzyć, snuć przypuszczenia i domniemania, wytwarzać fikcje na własny użytek, a i tak pozostaniemy bezradni”.

Ważnym elementem w poezji Fetlińskiej pozostaje język. Pozwala on opisać poetycki świat, ale jest także narządem smaku i dotyku, co pociąga za sobą zmysłowe konsekwencje. Intymność wierszy znajduje potwierdzenie nie tylko w dedykacjach patronujących niemal wszystkim tekstom, lecz przede wszystkim w somatycznym wymiarze poznania, o którym autorka często wspomina, jednocześnie zwracając uwagę na to, że człowiek jest istotą czysto biologiczną ${ }^{4}$.

Mam wrażenie, że to jest właśnie osławiona śmierć autora, a może raczej jego mord na zamówienie, dokonany ręką spolegliwego deskryptora poetyckiego trudu. Tymczasem tomik Fetlińskiej - i w ogóle, chyba, jej poezja - zasługuje na życie. A ja, jako krytyk, jestem za życiem. Poezja Fetlińskiej zasługuje na to życie z wielu powodów, nawet tak banalnych jak język, do którego jeszcze wrócę; teraz zasygnalizuję jedynie ogólne właściwości. Agata Pyzik dostrzegła, że w Sekstaśmach ten język „jest zarazem infantylny i dekadencki. To język poetyckiego baroku, internet baroque, w którym przebywanie w sieci i modernizm poetycki

4 http://portliteracki.pl/biuro/newsy/katarzyna-fetlinska-sekstasmy-2/ [dostęp: 20 lutego 2017]. 
w sposób naturalny znajdują swoje dopełnienie" [Pyzik 2017]. Mniejsza o trudną do usprawiedliwienia paralelę pomiędzy barokiem a modernizmem. Krytyczka „Dwutygodnika” ma bez wątpienia rację. Coś jest tutaj na rzeczy. Język poetycki Fetlińskiej uderza swoistą dwuskalowością, łączy wysokie z niskim, konkretne z abstrakcyjnym, erudycyjne z kolokwialnym. Miesza wulgarne ze wzniosłym, piękne z brzydkim, spontaniczne z wykalkulowanym, wreszcie, wracając do kwestii głosu autora, samoswoje z nieswoim. Cytując rówieśnika Fetlińskiej, popkulturowego twórcę, występującego pod pseudonimem Taco Hemingway, ów język jest jak „praska dziunia w stroju disco-barokowym” [Pyzik 2017].

Co więcej, przy całej językowej śmiałości, odwadze, brawurze Fetlińska jest jednym z pierwszych nieironicznych poetów w liryce polskiej po 1989 roku. Recenzentka powiada, że ktoś musiał w końcu „odzyskać pozytywne znaczenie pretensjonalności”, ponieważ „zbyt wiele świetnych rzeczy literackich, muzycznych i tych pomiędzy znika ze wstydu, po tym, jak zostają obdarzone taką łatką”. Racja: pretensjonalny to koniec końców „mający pretensje”, „ambitny, celujący ponad swoje umiejętności, odrzucający to, co zastane, kogoś lub coś udający, sztuczny, próbujący być czymś, czym nie jest. To coś, co nie chce być świętoszkowato «autentyczne» i zarazem odrzuca do mdłości przechodzoną ironiczność" [Pyzik 2017].

Nie wiem, czy zgodziłbym się całkowicie ze zdaniem Pyzik, która twierdzi, że „do bólu pretensjonalni byli David Bowie, Roxy Music, Depeche Mode, Ronald Firbank, John Ashbery, T.S. Eliot, John Donne”. Tudzież, że „pretensjonalność to doprawdy ostatnia deska ratunku, jeśli chcemy się jeszcze trochę zabawić" [Puzik 2017]. Mam wątpliwości, czy o zabawienie się - na śmierć zapewne - tu najczęściej idzie. Humor nie jest, bynajmniej, jowialny, a i dostrzegany tu i ówdzie wigor nie jest zanadto witalny. Trudno o większą krzywdę dla tej poezji niż stwierdzenie, że autorka „nie wstydzi się swojej kobiecości, czy raczej dziewczyńskości, z wdziękiem akcentuje młodzieńczą seksualność i niedojrzałość" [Pyzik 2017].

Stanowczo nazbyt ciężki ten wdzięk, co uzmysławia już pierwszy wiersz zbiorku, High definition: 
$[\ldots]$ bóg nie chce, aby

kto złym byl, więc zróbmy sobie dobrze. [...]

$[\ldots]$

Bądź przy mnie, proszę; a wetknę

ci tak głęboko, że włosy zaczną iskrzyć. Jesteśmy

dla siebie stworzeni. Jesteśmy złudzeni.

$[\ldots]$

[...] Stworzymy wtasne Kroniki Wypadków

Mitosnych - przypadkowe kobiety nagle przebite

kolumną kierownicy i wytrysk

benzyny na plac pokryty makadamem. $[\ldots]$

telefon drżący w pochwie. No, odbierz mnie, a potem pogrzebmy razem w ropie i w głowach, szukając resztek. Rzeczywistych.

[Fetlińska 2015: 5-6]

Aluzje do tekstów kultury nie są wszak z pewnością lekkie. Lautréamontowskie ewokacje zwodzą papierową nieważkością, leży za nimi stos ciężkiej pogiętej blachy, zmieszanej z krwią oraz innymi płynami fizjologicznymi kochanków, zupełnie jak w okrutnej i poplątanej Kraksie Ballarda. Nadmiarowa, nienormatywna seksualność nie polega li tylko na obcowaniu słów, skłębionych obrazów, epatujących konceptualnym erotyzmem. Te słowa i obrazy wydają się sugestywną emanacją wystygłego psychicznego wnętrza, docierają z ponurych głębin ludzkiej samotności. Warto przywołać inne, równie głośne dzieło o dramacie niemożności porozumienia, daremności prób zrozumienia drugiego i siebie: bohaterowie Ostatniego tanga w Paryżu nie szukali w zakamarkach swoich ciał telefonów komórkowych. Oni właśnie „grzebali w ropie i w głowach, szukając resztek. Rzeczywistych" [Fetlińska 2016: 6].

Wróćmy jednak do Ballarda, gdyż autorka sama doń wraca zaraz w następnym wierszu tomu: 
[...] na jej udzie powoli zasycha

lepki odcisk ręki. Łudząc drżeniem palców,

trwają w przedłużeniu - jej pleców tapicerka,

stóp szlachetne drewno, papieros jak wydech, konie mechaniczne w piersi. W trzewiach świece, sprzęgło. Karesy w karoserii. Bezimiennie się pieszczą, opatrzeni tabliczką: trzy litery, numer. Co po nich zostało? Licznik kilometrów i kropla Oleju jak łza zapomniana w betonie.

[Fetlińska 2015: 7]

Można dostrzegać w owym fragmencie jedynie ekfrastyczne paralele z Ballardiańskim pomieszaniem „technologii, seksu i neurozy” [Pyzik 2017]. Można także zżymać się na lingwistycznie desperackie „karesy w karoserii” [Pyzik 2017]. Ale bez wątpienia topika nietrwałości i bezimienności - niczym w znanej figurze nomina nuda tenemus z początków drugiego milenium - znajduje tutaj nowy wyraz, właściwy współczesnemu tysiącleciu.

Podobnie - jak sądzę - wielopłaszczyznowe są cytaty z minionej rzeczywistości transformacyjnej Polski. W wierszu Stadion oszalat poświęconym reminiscencjom z okresu świetności największego jarmarku Europy czytamy:

Miejski stadion wyłania się

zza drzew niby płytki wulkan, grzmiąc krzykiem przekupek, przechwałkami handlarzy kosmetyków Shanel, hurtem pachną wkoło markowe perfumy Cuggi, Estacada, egzotyczne owoce: pajpaje z rajskich wysp, tangerynki, grajfruty oblane rumieńcem, awokadła śliskie, w zielonkawych gruzłach jak beznogie ciała żab;

[...] pragnęłam mieć to wszystko, lecz zawsze mówiłaś, że niezdrowe, tandetne, podrabiane,

że brzydkie; i targnąwszy za rękaw, wciągałaś w poczucie, iż należy gardzić tym, co wzbudza podziw - 
mijałyśmy więc z daleka stragany z książkami, cukiernie oraz filmy o nadzwyczaj kuszących tytułach (Onan Barbarzyńca, Dupciuszek, Dlaczego nie, Anal z Zielonego Wzgórza) - czasem cię pytałam, czego my właściwie tu szukamy, jak mam wywnioskować, co z tego jest dobre, co prawdziwie piękne; no i całym sercem wierzyłam, że gdzieś musi być inny stadion, z piekarnią i kinem, gdzie rowery błyszczą

nowością i nikogo nie cieszy niedola tych biedaków Niemców, gdzie Cyganki pląsają w rytm orkiestry dętej, pali się Gauloises, pije wódkę Belvedere i zapiera dech $w$ piersiach widok z góry na miasto, bo ów stadion być musi gdzieś wysoko, w chmurach, by - obowiązkowo - wjeżdżać doń kolejką. [Fetlińska 2015: 10-11]

Słyszymy w tym fragmencie jakąś niechybną prawdę o emancypującej się siermiężnie postkomunistycznej Polsce, o sfalsyfikowanym marzeniu o kapitalistycznym dobrostanie, o podrobionej tęsknocie do komfortu zachodniego świata - wypowiedzianą głosem pokolenia „milenialsów”. To przecie nie Różewicz z Ballady o naszych sprawozdawcach sportowych, nie brutalnie weredyczni barbarzyńcy z „brulionu”, ale i też nie „młodzi wkurwieni” z roczników 70., czy nawet nie Masłowska - by z braku porównywalnie głośnej reprezentacji poetyckiej urodzonych w latach 80. sięgnąć po przedstawicielkę prozy

To prawda, „nikogo nie cieszy niedola tych biedaków Niemców". Jedno z najlepszych, a w każdym razie najzabawniejszych zdań zbioru. Mógłby je napisać Marcin Świetlicki w stylu rodem ze swojego prowokacyjnego wiersza-piosenki Brejkam wszystkie rule: „Niemców uwielbiam od dziecka”. Fetlińska jednak nie jest

5 Maja Staśko stanowczo domagała się podczas konferencyjnej dyskusji wpisania tutaj nazwisk takich poetów, jak Szczepan Kopyt czy Kira Pietrek. Abstrahując nawet od tak ostrych ideowych wyborów, warto spojrzeć na poezję Fetlińskiej w kontekście innych poetek, starszych lub prawie rówieśnych, obecnych choćby $\mathrm{w}$ antologii warkoczami [Głuszak, Gula, Mueller, red. 2016]. 
Świetlickim i nie ucieknie zaraz w wyłączającą sprawstwo i odpowiedzialność autora ironię. Przeciwnie, z dziecięcym resentymentem dokona apologii „klisz i kiczu” w nader grubo zatytułowanym wierszu Grobing, wspominając z dziecięcej perspektywy, jak w listopadowy poranek:

[... ogorzała twarz słońca ślizgała się chwiejnie po powierzchni pomników, podświetlając napisy - popis

[klisz i kiczu:

„Dla świata byłeś cząstką, dla mnie całym światem”, „Mój

[Boże,

co za żal...”, „Zmartwychwstanę niebawem”, „Śpij, mój

[Aniołku”.

[Fetlińska 2015: 12]

Ta infantylizująca narracja jest też zupełnie inna niż choćby nostalgiczne retrospekcje Krzysztofa Siwczyka z Dzikich dzieci. Okrutniejsza, bliższa Goldingowskiemu Władcy much w deziluzyjnej wizji przemocy i okrucieństwa, biorących się ze zwierzęcej biologiczności, z - by tak rzec - naturalnych praw dziecięcej dżungli etycznej:

Wieczorami, skuci śniegiem i kolcami głogu, podziwialiśmy córkę stolarza krążącą na łyżwach po orbicie stawu - jak ogon komety ciągnął się za nią warkocz, wierny obłok gazów, i pył

pryskał spod płóz, póki trwała zima - czas dorodnych gili. Zmierzch mierzwil pola, a my w światłoczułych świerkach, na terenie szkoły kolejno grzmociliśmy jej łyżwiarską dupę -

jakże miło wspominać młodzieńcze rozkosze! Wplatanie we włosy zżutych listków gumy bądź ropuchy pompowane przez słomkę - blady balon brzucha pękał $\mathrm{z}$ hukiem procy $[\ldots]$.

[Fetlińska 2015: 14] 
Darujmy już sobie ciąg dalszy Szkoły uczuć z motywem gry w zbijaka chomikiem i z koleżanką zmiażdżoną tablicą. Wystarczająco to bezlitosne i niekorczakowskie z ducha i litery. Ale nawet to, co wydawać się może z pozoru pensjonarsko sentymentalne - jak choćby obrazy z Wesolego miasteczka:

Chichoczą podlotki usadzone okrakiem, przypadkowo przeszyte

orgazmem kołyszą biodrami i drapie je $\mathrm{w}$ płucach, bo wessaty kometę. $[\ldots]$

[... Iskają się dziewczęta, mrucząc

o wojażach, wojakach $\mathrm{z}$ wieńcem róż pod pachą, włochatych i czułych

[Fetlińska 2015: 17-18]

- za chwilę straci swój inicjalno-imaginacyjny czar:

Nie nudzą wyprawy

w przestrzeń, gdzie kwitną kartofle, psy dupami szczekają oraz baby wyją do księżyca. [...]

choć pewnikiem upadną prędzej, później z rykiem. Będą chcieli stanąć, zgorzkniali i głodni, ustąpiwszy zdrowszym, młodym. I nie będą mogli.

[Fetlińska 2015: 18]

Fetlińska zdaje się też jedną z pierwszych w Polsce poetek poetów zapewne także - umiejących tak celnie zadać cios skandalicznej metafizycznie rzeczywistości narzędziami najprymitywniejszymi, nielicującymi z powagą mowy wiązanej: popem i porno. Takie próby już podejmowano $\mathrm{w}$ historii rodzimej literatury. Libertyni, skamandryci, futuryści, brulioniści, a nawet grzeczne 
poetki z telewizji dla czytających oraz czasopism dla kobiet (przez wzgląd na przyszłe interakcje zawodowo-towarzyskie oszczędzę tutaj nazwisk). Ale nikt tak mocno, przepraszam za wyrażenie, nie przywalał dotąd jak Fetlińska.

Cytaty z Michała Wiśniewskiego: „Piję kawę, jest cudownie, pocałunków lekka pianka / stodko pieści suche usta, moja panna filiżanka” [Fetlińska 2015: 19] czy z Kasi Kowalskiej: „Fortuna się kołem nie toczy, / fortuna się toczy owocem" [Fetlińska 2015: 30] zderzone z ewokacjami mrocznej i znakomitej (aż boję się, że to falsyfikat samej Fetlińskiej) pieśni o grzybach z początku wieku XX via audycja Kraina Grzybów Tv [Fetlińska 2015: 35], jak też sentencje komórkowe z pociągu: „Ważne, że jadę / PKP” w tym samym motcie obok wersetów św. Jana od Krzyża: „Aby mieć wszystko / Nie chciej posiadać czegoś w Niczym" [Fetlińska 2015: 23] - są bezsprzecznie apogeum podobnych prowokacyjnych koniunkcji.

No i pornografia: ostateczny policzek wymierzony miałkości, nicości. Jak w wierszu 2girlsicup (głupio dodawać, że to domena pornograficznego serwisu). By tak rzec za Jonathanem Swiftem, grobianizm przeciw grubiaństwu:

\section{$[\ldots]$ Spocone}

filiżanki, fajanse. Przyspieszamy krążenie i skurcze okrężnic, poprawiając pamięć, jak łaskun śnimy o bogactwach: kokosach w pergolach i sraniu na spodek

aromatycznym luwakiem. $[\ldots]$

[Fetlińska 2015: 19]

Takie to Kuchenne rewolucje - kawa z odchodów łaskuna. Taki Kac Vegas czy raczej, jak brzmi tytuł wiersza Fetlińskiej, a nie znanego gniota filmowego, Los Milionos:

[...] Każdy pragnie

szczęścia - kilka dodatkowych zer, premia,

trzy węgierki na stole - i już 
są w Las Vegas jurni hazardziści

w klapkach od Kubota. One - nadrabiają różem, pozłacanym cieniem, chłodzą łokcie w oknach. Byle do soboty, byle w snach zobaczyć, jak kwitną marakuje; [...]

\section{[...] Dojrzałym}

wystarczy jedna dłoń i cytryny jędrne na wysokość piersi, mechaniczna wnęka, aby wkładać częściej, więcej. Inwestować w przyszłość, wypełniając pustkę. [...] [Fetlińska 2015: 30]

Takie Last minute z hedonistyczną przysięgą:

„przelecę cię jak Atlantyk”,

za worek dolarów kupiwszy aeroplan w demobilu armii, naprawdę go przelecieć jako pierwsza kobieta; założyć ci furażerkę, zrobić nagi portret rozkraczonej, na plecach, a później na tropiki obrawszy azymut, pieścić gładki kadłub, wypełnić ładownię, aż w końcu, przeżywszy kapotaż lub inną katastrofę, usłyszeć gdzieś w radio, że „wśród ofiar nie było, tym razem, Polaków”. [Fetlińska 2015: 37-38]

Autorka portretuje swoje rówieśniczki, ich matki i babki, skazane na Faszyn from Raszyn albo na Sylwestra z Polsatem - na życie mierne i nadzieje płonne. $\mathrm{Na}$ „klepnięcia w pośladki” od podpitych bliskich znajomych tudzież „ciche pociski” [Fetlińska 2015: 25] - czyżby to, toutes proportions gardées, jakiś wariant „pocisków zawistnego losu" - od bliżej niezidentyfikowanego Absolutu. Skazane na posiadanie męża albo przynajmniej chłopaka, gdyż

[...] świat gardzi spisanymi na straty:

musisz coś do siebie dodać, się obłożyć, 
zostawić potomnym, wpełzając pod górę jak wąsy męczennicy po gotyckim murze.

[Fetlińska 2015: 32]

Fetlińska, co widać wyraźnie na przykładzie drugiej książki poetyckiej, zgromadziła już swój arsenał do rozprawy z tym okrutnym porządkiem: ludzkim i biologicznym. Uprawia na bardzo dobrym poziomie i z naprawdę niezłym skutkiem - że tak to określę - mieszane sztuki walki. Miesza choćby - jak świetnie skonkludowała Pyzik - „Kim Kardashian z Sørenem Kierkegaardem, jak na popularnym koncie na twitterze” [Pyzik 2017]. Nie sądzę, aby zapożyczała się u rodzimych nestorów tej techniki, konceptualistów typu Andrzeja Sosnowskiego albo Tadeusza Pióry. Jest głodna własnego stylu, nie zadowala się przejęciem czy przetworzeniem znanych chwytów.

Skoro już wywołałem - oczywiście w trybie relata refero - Kim Kardashian: sekstaśma jest sprawdzoną bronią w czasach postkulturowego czy podkulturowego terroru mediów społecznościowych. Umiejętnie użyta, pozwala walczyć z uprzedmiotowieniem, trywializacją, śmiesznością niejako na integralnych zasadach, bo wystawiając pupę, uprzedza się upupienie. Powrócę do przykładu Masłowskiej, która zwłaszcza w Pawiu królowej zmierzyła się na własnych warunkach z trzecią rzeszą popkultury. I wygrała. Fetlińskiej też się to najpewniej uda. Nie wygra jednak z biologią, choć dziś jest piękna i młoda. Ale o tym już wie:

\section{Azorowi}

Strzeż się tej krainy grzybów, choć stoneczna kusi łąkakto swe kroki tam skieruje, temu jeno płacz, rozłąka. pieśń z początku xx wieku (Kraina Grzybów Tv)

Na przestrzeni pokoleń i podmokłych polan rozpierzchli się z nadzieją na pełen kosz, wiadro 
odbarwione $\mathrm{z}$ brzękiem, kieszeń, miskę albo wypchanie skarpety. Ty pomiędzy nimi

stałaś w kapeluszu, przytwierdzona do ściółki, jedną jędrną nóżką, bez pierścienia pochwiasta i śliska od śluzu. Kusiłaś, by cię wyrwać, świeżą pieprząc, dusić, zanim się rozłożysz

jak dziadkowie ( w mchu, pod kropidłem pleśni błyszczał oklapnięty trzonek, mufka posiwiała wokoło zarodni, nad głową zwisały przywiędłe obrazki - wschodnie, typowe) bądź rodzice,

którzy suszyli się jak figi na rozpiętym sznurze. Wkrótce wszyscy odeszli, niepewni, na czym stoją i co dalej robić. Hop, hop, ratunku - krzyczeli pechowcy; mam grzyba - niektóre kobiety

niosły smardze w spódnicy, mężczyźni jak rydze tryskający mleczkiem podczas snu o trufli. Minęło kilka godzin, zrobiło się pusto. Ciemno. Słychać tylko deszcz odbity od ziemi i mięśni

pomrowów, lecz jutro przyjdą kolejni kolonizatorzy lasów, sklepów, naszych ciał i domostw; będą trawić resztki - ślepi, głusi, niemi, nieświadomi - po co? [Grzybobranie, Fetlińska 2015: 35-36]

\section{Bibliografia}

Fetlińska Katarzyna (2012), Glossolalia, Biuro Literackie, Wrocław. Fetlińska Katarzyna (2015), Sekstaśmy, Biuro Literackie, Wrocław. Głuszak Sylwia, Gula Beata, Mueller Joanna (2016), warkoczami.

Antologia nowej poezji (2016), Staromiejski Dom Kultury, Warszawa. Połów. Poetyckie debiuty (2011), Biuro Literackie, Wrocław.

Pyzik Agata (2015), Pensjonarsko, „Dwutygodnik”, wydanie 169, nr 10, http://www.dwutygodnik.com/artykul/6163-pensjonarsko.html [dostęp: 20 lutego 2017]. 
Piotr Łuszczykiewicz

Sex, tapes and Facebook statuses. On the poetry of Katarzyna

\section{Fetlińska}

The article attempts to analyze the poetry of Katarzyna Fetlinska with the main stress laid upon her volume Sekstaśmy (Sex Tapes). The author tries to verify critical tracks and generalizations, introduced mostly by editorial and publishing descriptions which promote the collection. He exposes the importance of dramatic and surprisingly non-ironic themes chosen by the poet, who confronts herself with the most tragic aspects of human existence: loneliness and death. The main theme of the sketch is eroticism, sexuality and even pornographic character of her poetry, directed against metaphysically scandalous friability of interpersonal relations, human objectification and nothingness of being.

Keywords: Katarzyna Fetlińska; the new Polish poetry; eroticism; pornography.

Piotr Łuszczykiewicz - od 1992 roku pracuje na Uniwersytecie im. Adama Mickiewicza w Poznaniu, obecnie - po uzyskaniu stopnia doktora habilitowanego na podstawie dysertacji Piosenka w poezji pokolenia ery transformacji 1984-2009 - jako profesor nadzwyczajny. Od 2016 roku pełni funkcję dziekana Wydziału Pedagogiczno-Artystycznego w Kaliszu UAM w Poznaniu oraz kierownika Zakładu Studiów Polonistycznych i Komunikacji Medialnej. Członek Stowarzyszenia Pisarzy Polskich. Wydał sześć książek i dwa obcojęzyczne skrypty. Ogłosił kilkadziesiąt artykułów naukowych oraz kilkaset recenzji. 